
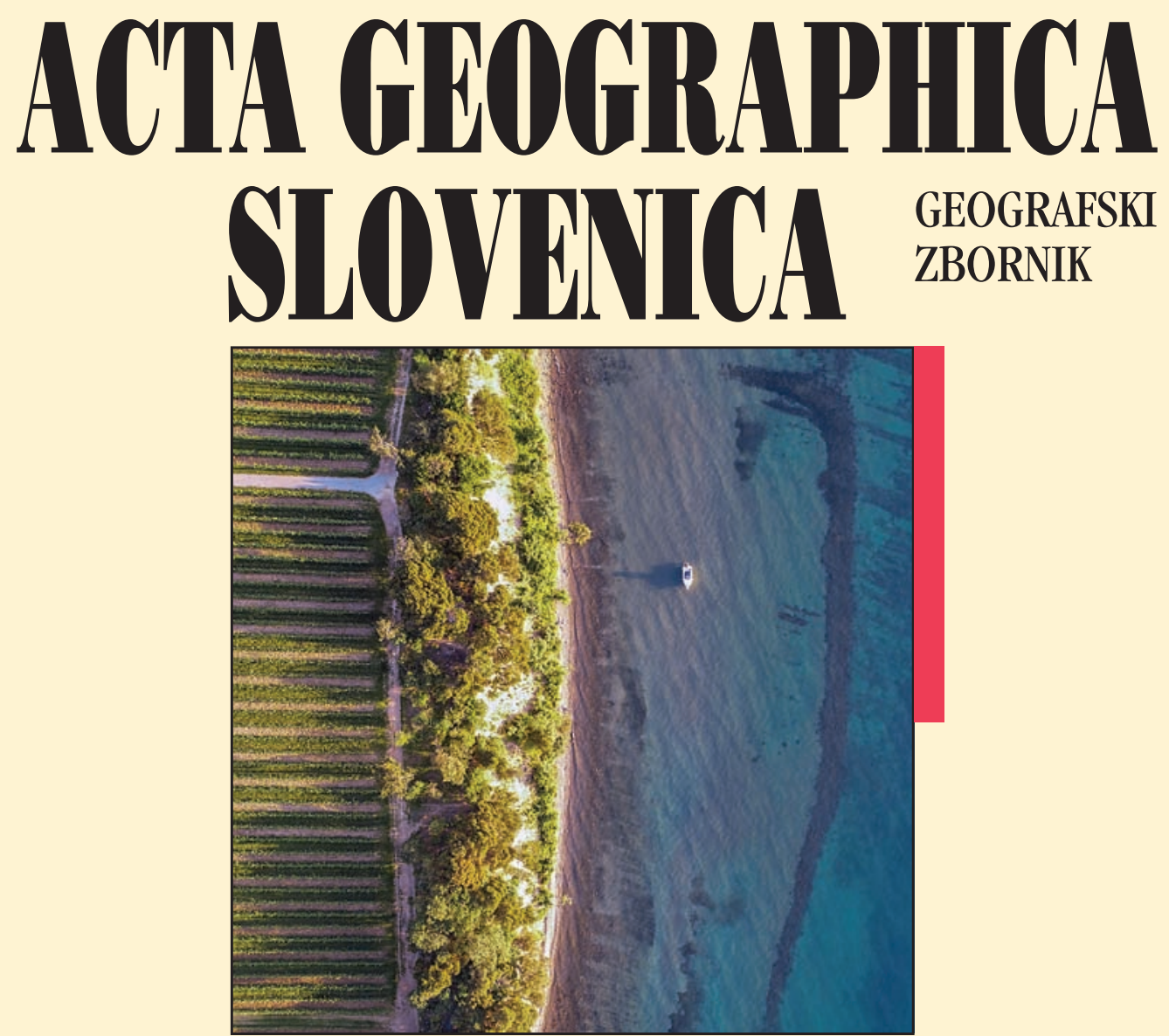


\section{ACTA GEOGRAPHICA SLOVENICA GEOGRAFSKI ZBORNIK 60-1 - 2020}

\section{Contents}

Mojca POKLAR

Comparison of the sonar recording method and the aerial photography method

for mapping seagrass meadows

Vanja PAVLUKOVIĆ, Uglješa STANKOV, Daniela ARSENOVIĆ

Social impacts of music festivals: A comparative study of Sziget (Hungary) and Exit (Serbia)

Péter János KISS, Csaba TÖLGYESI, Imola BÓNI, László ERDÖS, András VOJTKÓ, István Elek MAÁK, Zoltán BÁTORI

The effects of intensive logging on the capacity of karst dolines to provide potential microrefugia for cool-adapted plants

Radu SĂGEATĂ

Commercial services and urban space reconversion in Romania (1990-2017)

Kristina IVANČIČ, Jernej JEŽ, Blaž MILANIČ, Špela KUMELJ, Andrej ŠMUC Application of a mass movement susceptibility model in the heterogeneous Miocene clastic successions of the Slovenj Gradec Basin, northeast Slovenia

Andrej GOSAR

Measurements of tectonic micro-displacements within the Idrija fault zone in the Učja valley (W Slovenia)

Piotr RAŹNIAK, Sławomir DOROCKI, Anna WINIARCZYK-RAŹNIAK

Economic resilience of the command and control function of cities in Central and Eastern Europe

Mateja FERK, Rok CIGLIČ, Blaž KOMAC, Dénes LÓCZY

Management of small retention ponds and their impact on flood hazard prevention in the Slovenske Gorice Hills

\section{Gregor KOVAČIČ}

Sediment production in flysch badlands: A case study from Slovenian Istria

Vesna LUKIĆ, Aleksandar TOMAŠEVIĆ

Immigrant integration regimes in Europe: Incorporating the Western Balkan countries

Mitja DURNIK

Community development: Local Immigration Partnerships in Canada and implications for Slovenia

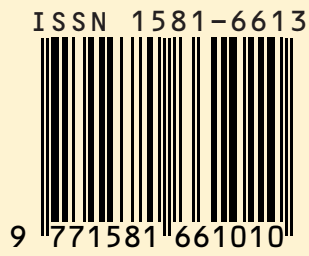




\section{MEASUREMENTS OF TECTONIC MICRO-DISPLACEMENTS WITHIN THE IDRIJA FAULT ZONE IN THE UČJA VALLEY (W SLOVENIA)}

Andrej Gosar

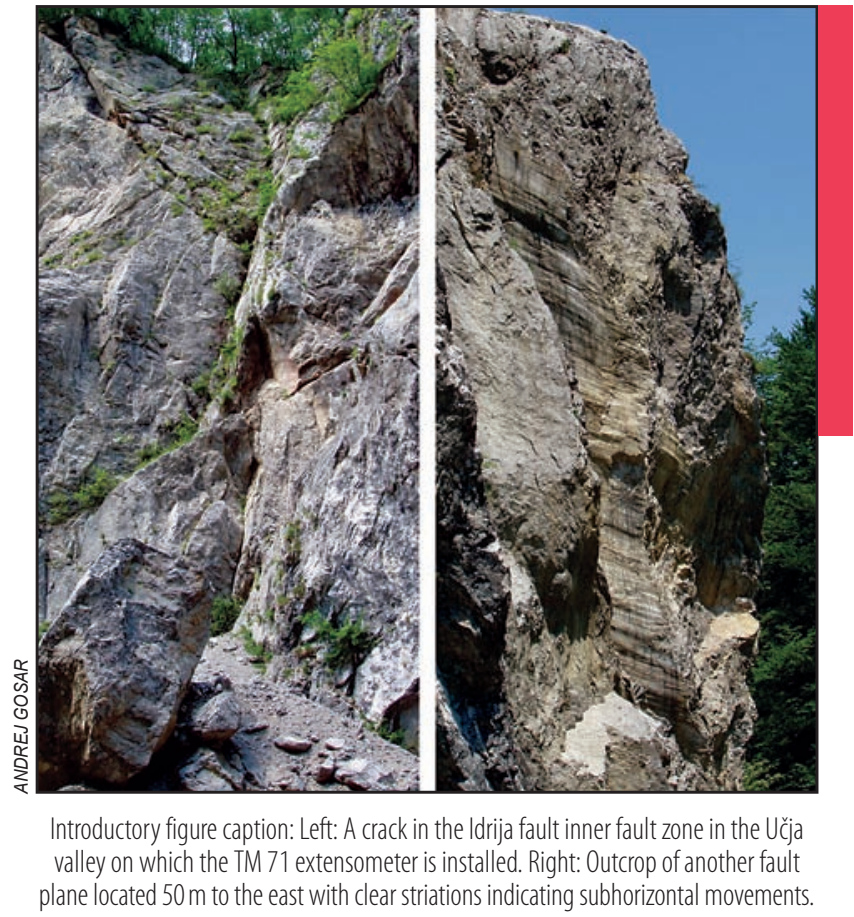


DOI: https://doi.org/10.3986/AGS.7444

UDC: 551.242:551.34(497.47)

COBISS: 1.01

Andrej Gosar ${ }^{1,2}$

\title{
Measurements of tectonic micro-displacements within the Idrija fault zone in the Učja valley (W Slovenia)
}

\begin{abstract}
A recent slip-rate of an active fault is a very important seismotectonic parameter, but not easy to determine. Idrija fault, $120 \mathrm{~km}$ long, is a prominent geomorphologic feature with large seismogenic potential, still needed to be researched. Measurements of tectonic micro-displacements can provide insight into its recent activity. The Učja valley extends transversally to the Idrija fault and was therefore selected for the installation of TM 71 extensometer. Measurements on the crack within its inner fault zone are conducted from the year 2004. In 14 years of observations a systematic horizontal displacements with average rate of $0.21 \mathrm{~mm} /$ year and subordinate vertical displacements of $0.06 \mathrm{~mm} /$ year were established, proving the activity of this fault. An overview of methods of displacement measurements related to active faults and of newer interdisciplinary investigations of the Idrija fault is given. Displacement rates are beside for geodynamic interpretations important for improvement of seismotectonic models and thus for better seismic hazard assessment.
\end{abstract}

KEY WORDS: tectonics, geodynamics, fault, extensometer, Idrija fault, Učja, Slovenia

\section{Meritve tektonskih mikro-premikov v prelomni coni Idrijskega preloma $\mathrm{v}$ dolini Učje (Z Slovenija)}

POVZETEK: Recentna hitrost premikov ob aktivnem prelomu je zelo pomemben seizmotektonski parameter, ki pa ga ni lahko določiti. Idrijski prelom je z dolžino $120 \mathrm{~km}$ pomembna geomorfološka struktura z velikim seizmogenim potencialom, ki pa ga je treba še raziskati. Meritve mikro-premikov lahko nudijo vpogled v recentno aktivnost preloma. Dolina Učje poteka prečno na Idrijski prelom, zaradi česar je bila izbrana za namestitev ekstenziometra TM 71. Meritve na razpoki v notranji prelomni coni potekajo od leta 2004. V 14 letih opazovanj je bilo ugotovljeno sistematično vodoravno zmikanje s povprečno hitrostjo $0,21 \mathrm{~mm} /$ leto in podrejeni vertikalni premiki s hitrostjo $0,06 \mathrm{~mm} /$ leto, kar dokazuje aktivnost tega preloma. Podan je pregled različnih metod raziskovanja recentnih premikov ob aktivnih prelomih ter novejših interdisciplinarnih raziskav Idrijskega preloma. Ocene hitrosti premikov so poleg geodinamskih interpretacij pomembne predvsem za izboljšanje seizmotektonskih modelov in s tem boljše ocenjevanje potresne nevarnosti.

KLJUČNE BESEDE: tektonika, geodinamika, prelom, ekstenziometer, Idrijski prelom, Učja, Slovenija

The paper was submitted for publication on $5^{\text {th }}$ June, 2019.

Uredništvo je prejelo prispevek 5. junija 2019.

\footnotetext{
${ }^{1}$ Slovenian Environment Agency, Seismology and Geology Office, Ljubljana, Slovenia

${ }^{2}$ University of Ljubljana, Faculty of Natural Sciences and Engineering

andrej.gosar@gov.si
} 


\section{Introduction}

A recent slip-rate of an active fault is among the most important seismotectonic parameters needed for realistic earthquake hazard assessment. However, it is not easy to determine it and interdisciplinary approach is needed for a reliable estimate. The methods applied so far on the Idrija fault or its vicinity can be grouped into a) geodetic (Kogoj9 2000; Rižnar, Koler and Bavec 2007; Weber et al. 2010), geological (Čar 2010), b) tectonic geomorphology (Moulin et al. 2014), c) paleoseismology (Bavec et al. 2013), d) outcrops dating methods (Moulin et al. 2016) and e) seismological (Bajc et al. 2001; Živčić et al. 2011). Measurements of tectonic micro-displacements using extensometer represent an additional method (Stemberk, Koštak and Vilimek 2003), which can contribute to the solution of the problem. Such measurements were enabled through invention of a crack-gauge instrument (Koštak 1991), which is installed on the crack which separates two tectonic blocks.

In Slovenia seven TM 71 extensometers were installed between 2004 and 2010 at or near the active faults, three of them on the surface (Idrija, Kneža and Raša faults) and four inside karst caves (two in Postojna cave, in Polog cave and in Kostanjevica cave) (Gosar et al. 2007, Gosar et al. 2011). Until 2011 the highest rates with stable sense of movements were observed on the Idrija fault (average horizontal displacement rate of $0.24 \mathrm{~mm} /$ year). The observed displacement rates (mainly horizontal) at all other locations were much smaller (from 0.006 to $0.05 \mathrm{~mm}$ /year). Only on the Raša fault more significant short-term vertical displacement rate of $0.16 \mathrm{~mm}$ /year was observed, at all other locations the rates were an order of magnitude smaller (Gosar et al. 2011). The fact that the monitoring on the Idrija fault showed with the leap the highest displacement rates in Slovenia, additional eight years of monitoring till 2019 and significance of the Idrija fault for earthquake hazard assessment and tectonic geomorphology, motivated a study dedicated only to the measuring site in the Učja valley which is presented in this paper.

Idrija fault is because of its length and prominent expression in topography one of the most important faults in Slovenia (Fig. 1) and it is supposed that it has a large seismogenic potential (Atanackov et al. $2014 ; 2016)$. However, its recent tectonic activity is not definitely proved yet by seismological monitoring or geodetic observations, but there are several indications for its activity from geological mapping, tectonic geomorphology, dating of outcrops and paleoseismological studies.

To get additional insight into the activity of the Idrija fault, we installed in 2004 the TM 71 extensometer on a crack within the inner fault cone which is exposed in the Učja valley (Figures 2 and 3). This location was selected as the best, because elsewhere along its trace there are no suitable outcrops. After 14 years of measurements, we provide the results of observed trends and displacement rates. First, an overview of interdisciplinary investigations of the Idrija fault is given. It is followed by description of different methods for displacement measurements and tectonic slip-rate estimates. The fault zone exposed in the Učja valley is described together with the selection of the location for the installation of extensometer. Observed microtectonic displacements are evaluated and some possible interpretations indicated.

\section{Idrija fault and measurements of tectonic displacements}

\subsection{Geology and geomorphology of the Idrija fault}

The Idrija fault is geomorphologically the most prominently expressed fault in W Slovenia and is clearly visible on satellite and aerial images or digital elevation models (Figure 1). Active tectonic movements are the only geological force which can influence the landscape in such a way. They can be studied by tectonic geomorphology methods or direct measurements along faults. The Idrija fault can be traced in the length of $120 \mathrm{~km}$ from Friuli (Italy) on the NW (Figure 1) to Gorski Kotar in Croatia on the SE (Buser 1986). Its average strike direction is $310^{\circ}$, and the dip $85^{\circ}$ (Atanackov et al. 2014; 2016). In the southern part there are several karst poljes of the Ljubljanica river system distributed along the fault. In the northern part the fault extends along the Idrijca, Kanomljica and Soča river valleys (Figure 1). The history of its investigations is very long (Čar and Gosar 2011), also due to the importance of the Idrija Hg ore deposits, because in the geological history part of the ore body (Ljubevč) was displaced along the fault for approximately $2.5 \mathrm{~km}$ to its present position. Based on this fact and considering the supposed age of the fault of 10-12 million years, Placer (1971) estimated that the average slip-rate through the whole period was from 0.25 


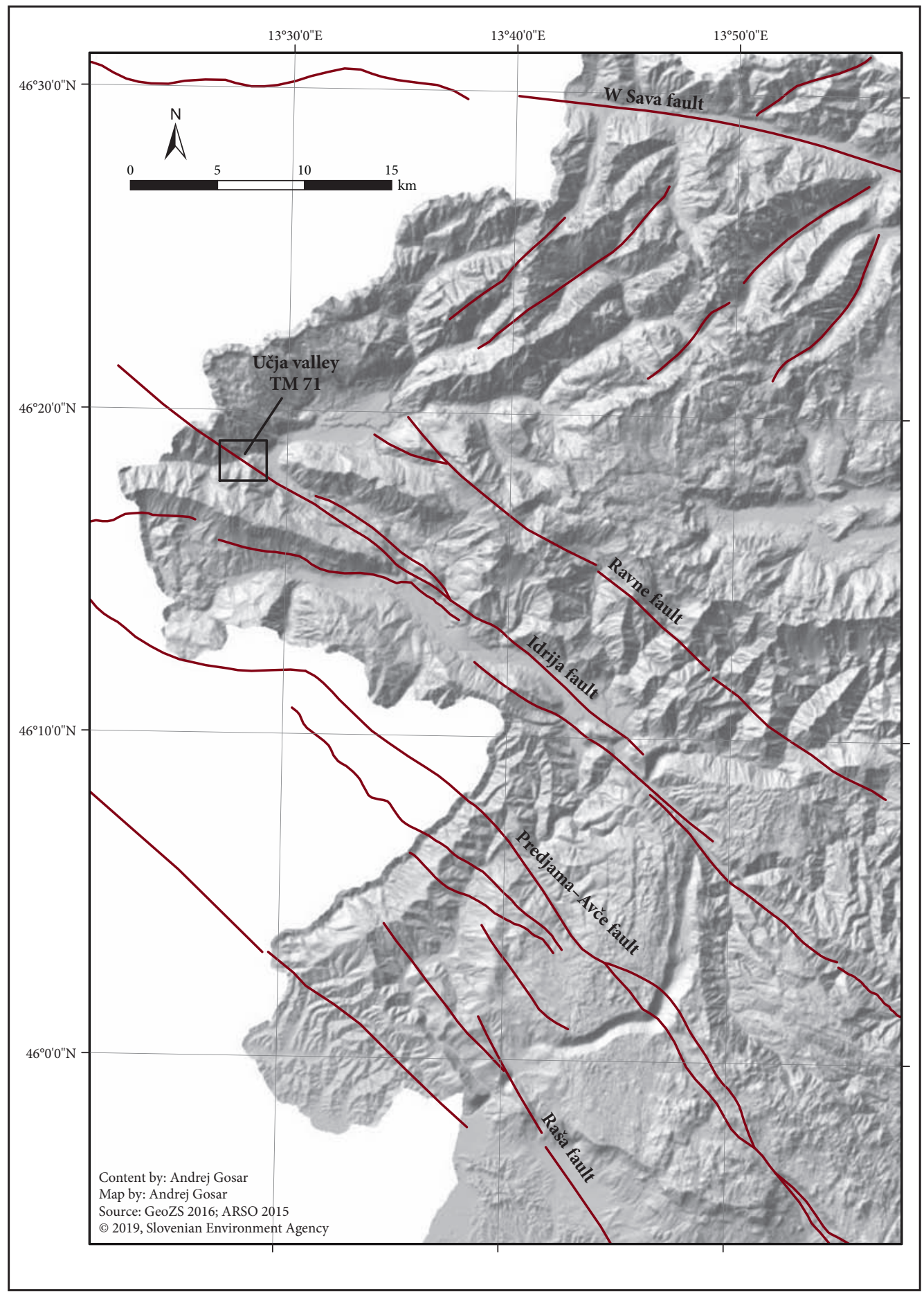

Figure 1: Map of active tectonic faults in NW Slovenia (after Atanackov et al. 2014; 2016) on shaded LiDAR $1 \mathrm{~m}$ resolution digital elevation model (ARSO 2015) with the location of TM 71 extensometer on the Idrija fault in the Učja valley. The rectangle indicates a detailed map shown in Figure 2. 
to $0.16 \mathrm{~mm} /$ year, and the slip was oblique with vertical displacement of $480 \mathrm{~m}$ (Placer 1982). Newer investigations also shown oblique displacement, which is the result of two separated tectonic phases (Čar 2010). In middle Miocene, 12 million years ago, the area was under strong extensional forces and normal faults were developed in NW-SE direction dipping towards the NE. Along the Idrija fault the NE block was lowered for up to $480 \mathrm{~m}$ (Čar and Gosar 2011). Later the stress regime has changed to compression in approx. $\mathrm{N}-\mathrm{S}$ direction and the fault was reactivated as a dextral strike-slip (Čar 2010). Related to this change some new fault traces were developed. Due to this fact the whole fault zone is rather complex. In a newer study Placer, Vrabec and Celarc (2010) made an estimate that the apparent displacement along the Idrija fault in Tolmin area is around $10 \mathrm{~km}$. Because the Idrija fault runs mostly along river valleys and karst fields, there are very few outcrops suitable for detailed tectonic analyses.

The best exposure of the whole fault zone is in the Učja valley at the far NW end of the fault (Figures 1 and 2), because it extends in a transverse direction to the fault and at the location of the fault zone it forms a small canyon (Čar and Pišljar 1993). In this canyon the structures of outer and inner fault zones are very good visible (Figure 2). The direct evidence of Quaternary to recent deformation in this area was described by Vrabec (2012). He found an outcrop of poorly sorted Quaternary breccia, which is dissected by several NW-SE oriented subvertical faults and associated fractures. Activity of the fault is further indicated by dextral offsets of the Učja river coinciding with the strands of the Idrija fault zone.

Using the tectonic geomorphology (e.g. Žibret and Žibret 2014) and detailed LiDAR digital elevation model, recent kinematics of the Idrija fault was studied by Moulin et al. (2014). Later they applied also the dating methods based on the exposure of outcrops to cosmic rays (isotope ${ }^{36} \mathrm{Cl}$ ) and estimated the average slip rate along the fault on $1.15 \mathrm{~mm}$ /year for late Pleistocene onwards (Moulin et al. 2016). In the frame of seismotectonic parameterisation of active faults in Slovenia, Atanackov et al. (2016) estimated the recent slip rate on $1 \mathrm{~mm} /$ year.

It is assumed that the Idrija fault is seismically active, although the number of earthquakes detected so far in its vicinity is rather low (Živčić et al. 2011; Vičič et al. 2019). However, the fact that seismic stations were in the past located at relatively large distances, contributes to the large extent to the uncertainty of determinations. For the Idrija earthquake in 1511 with estimated magnitude of 6.8 , it is supposed that it occurred in the wider area of the Idrija fault. However, the exact location of this event is still subject of investigations (Fitzko et al. 2005). Recently, the most important investigations of this subject are paleoseismological (Bavec et al. 2013). In the $20^{\text {th }}$ century in a wider area of the Idrija fault two strong earthquakes happened, the Cerknica one in 1926 and the 1998 in Krn Mountains (Živčić et al. 2011).

\subsection{Measurements of tectonic displacements}

Estimates on recent slip-rates are very important to understand active tectonics and tectonic geomorphology, as well as for earthquake hazard assessments. In the regions with moderate rates of deformations, including Slovenia, to measure recent slip-rates is not an easy task, especially if strong faults are characterised by rather wide fault zones. To accomplish the task the methods of terrestrial and satellite geodesy are used. In the past several repeated levelling measurements were conducted along various infrastructure. They usually measured only vertical deformations, but horizontal displacements can be measured as well. In the western Slovenia vertical deformations were measured along the profile from Sečovlje to Bled (Rižnar, Koler and Bavec 2007) indicating faster uplift of the Julian Alps north of the Idrija fault with respect to the territory south of it. For detailed analysis of the activity of individual faults, geodetic measurements should be performed at locations where structural geological setting is well known and the fault zone is preferable not too wide. On the Idrija fault it was appraised that for terrestrial measurements a suitable transect is between Dolenja Trebuša and Kanomeljsko Razpotje (Čar and Gosar 2011). For this purpose a network of four points was deployed in the Kanomljica valley already in 1985, but only initial measurements were conducted (Kogoj 2000). For geodetic monitoring of active fault zones Placer and Koler (2007) proposed deployment of geodetic networks of points in both blocks outside the fault zones and long-term measurements.

Some investigations which include repeated GNSS measurements were also conducted (Weber et al. 2010; Serpelloni et al. 2016) in W Slovenia. They provided velocity vectors for wider area indicating general movements in the north direction for $2-3 \mathrm{~mm}$ /years. However, the density of measuring points was in general too low to enable assessment of displacements along individual faults. Besides GNSS measurements, for detection of vertical movements of the surface Synthetic Aperture Radar method of persistent scatterers 
(InSAR PS) is also used. This method was applied also in the Julian Alps, but not evaluated for tectonic deformations (Žibret, Komac and Jemec Auflič 2012).

With respect to the scale of measurement, on the other end, compared to satellite geodesy, are microdisplacement measurements on individual fault planes or cracks inside the fault zones (Stemberk, Koštak and Vilimek 2003), which are described in this paper. By their application we can prove the activity of a fault plane and thus activity of the fault, but we cannot assess the total deformation across the whole fault zone.

\section{The Idrija fault zone in the Učja valley}

In the Učja valley the Idrija fault zone is approximately $750 \mathrm{~m}$ wide (Figure 2). In the frame of COST project 3D monitoring of active tectonic structures it was geologically mapped by Igor Rižnar. The wider area is built mainly of upper Triassic Dachstein limestone. Slightly to the north, there is the main thrust of Kanin Mountains, along which the Dachstein limestone is overthrusted to the south on Cretaceous flysch (Buser 1986). To the SW of the main fault plane in the Učja valley there is a smaller area of Jurassic limestone, and in the canyon floor in some places Cretaceous flysch outcrops. The inner fault zone is approximately $260 \mathrm{~m}$ wide and comprises of two border faults, the main and side fault planes (Figure 2). Along the main fault plane we didn't find any suitable crack for micro-displacement measurements. On the other hand, the side fault plane which runs $70 \mathrm{~m}$ to the east across $50 \mathrm{~m}$ high canyon wall, represents a prominent crack (Figure 3a), which was found as the most appropriate for the installation of extensometer. Down the river to the east, there is another well exposed fault plane with striations which indicate subhorizontal movements (Figure $3 \mathrm{~b}$ ). However, the access to this narrow part of the canyon with equipment needed for the installation was not possible.

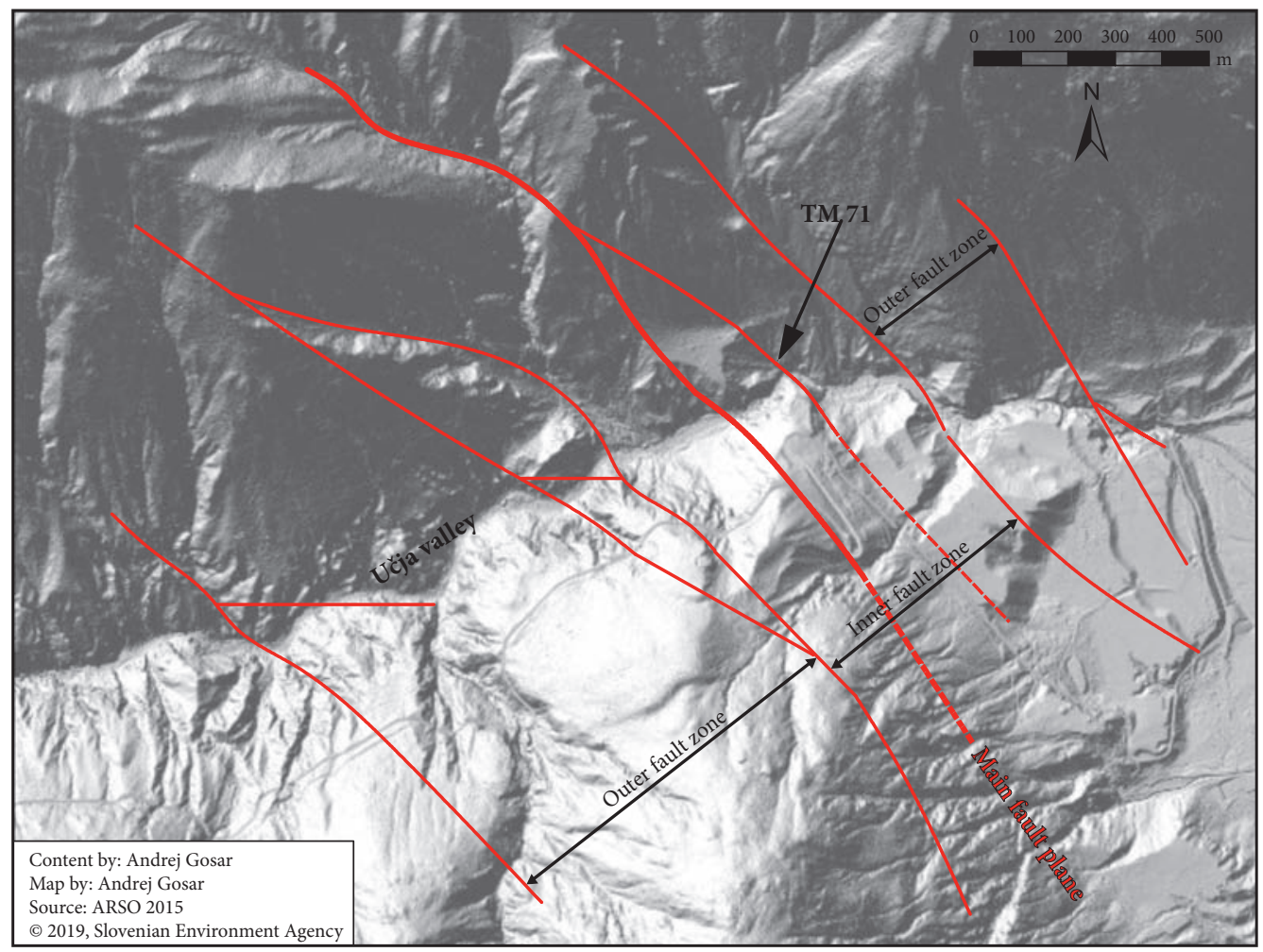

Figure 2: Detailed map of outer and inner fault zones of the Idrija fault in the Učja valley on shaded LiDAR $1 \mathrm{~m}$ resolution digital elevation model (ARSO 2015) with the location of TM 71 extensometer. 


\section{Methods}

\subsection{Extensometer TM 71}

TM 71 is a mechanic extensometer (Figure 4) aimed for installations on cracks to monitor relative microdisplacements of two tectonic blocks separated by the crack. It operates on the principle of Moire optical effect. Displacements are measured through interference pattern (Koštak 1977; Koštak 1991), formed by two optical grids engraved in two glass plates which undergo a relative shift. The instrument measures deformations in three dimensions as displacement vectors in two perpendicular planes (horizontal and vertical) and angular deviation (rotation). The accuracy of the instrument is $0.05-0.0125 \mathrm{~mm}$ for displacements and greater than $3.2 \times 10^{-4} \mathrm{rad}\left(0.018^{\circ}\right)$ for angular deviation (Stemberk, Koštak and Vilimek 2003; Stemberk, Koštak and Cacon et al. 2010). The main advantage of TM 71 is that it has no electric components and is thus very robust for operation in difficult outdoor conditions. Therefore, it is very suitable for long-term monitoring. A disadvantage is that it requires manual readings at regular intervals. However, this problem was recently solved for temperature stable and protected environments (for instance karst

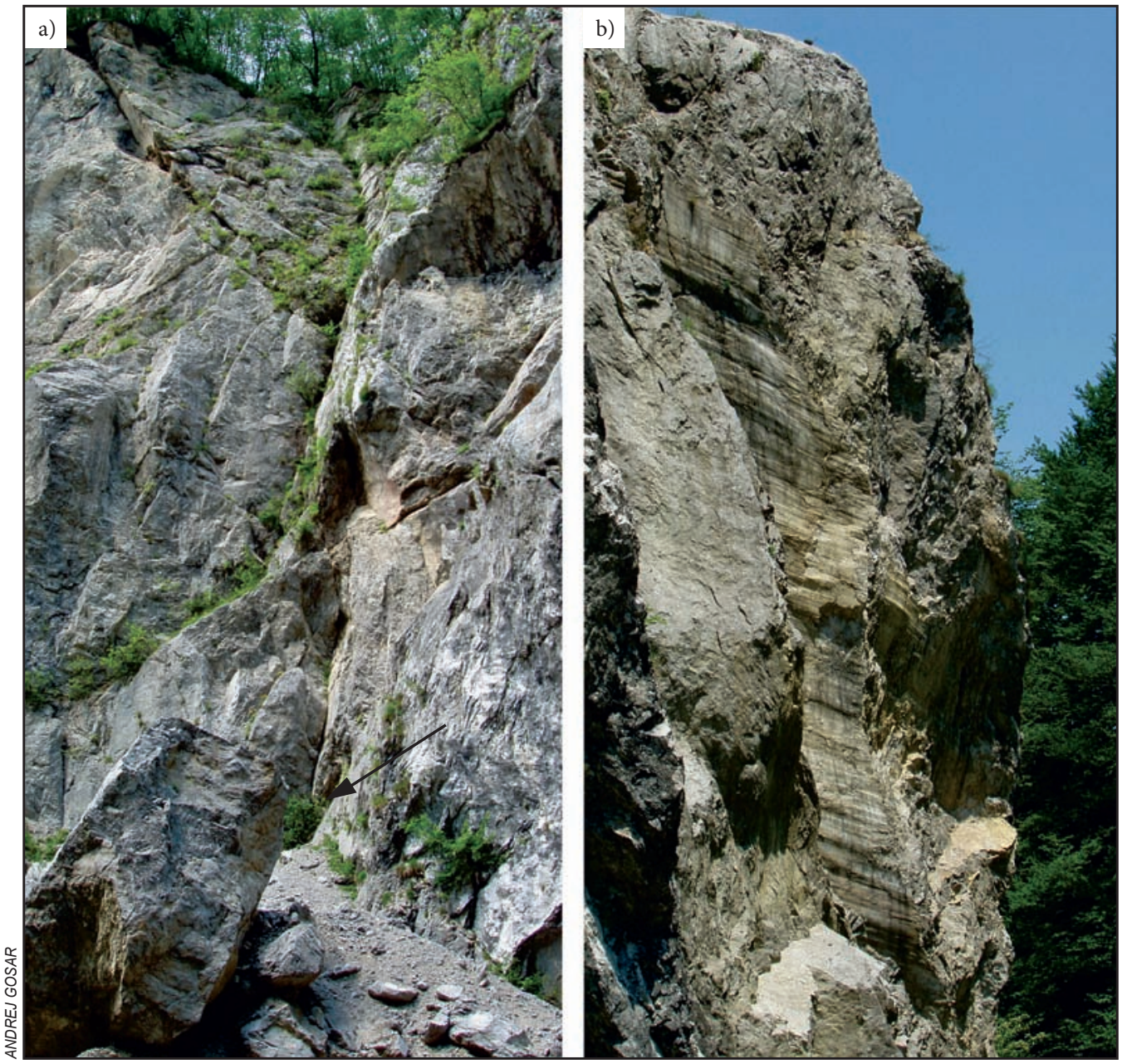

Figure 3: a) A crack in the Idrija fault inner fault zone in the Učja valley. Arrow indicates the location of the TM 71 extensometer. b) Outcrop of another fault plane located $50 \mathrm{~m}$ to the east with clear striations indicating subhorizontal movements (after Gosar 2007). 
caves) by automated shooting images of interference pattern in selected intervals (Briestensky et al. 2010; Šebela et al. 2009). Instrument readings are always corrected for temperature variations. Today almost 300 instruments are installed in the whole world. Beside measurements of tectonic displacements, it is used also in engineering geology for monitoring stability of rock blocks or landsliding.

\subsection{Measurements of tectonic micro-displacements in the Učja valley}

After detailed survey of the fault zone we selected, as the most suitable for installation of the TM 71, a prominent crack in the initial part of the canyon, which cut $50 \mathrm{~m}$ high south oriented face (Figure 3a). The crack extends across the whole face, and the installation was realised at the foot of it, above a large scree cone (Figures 3a and 5). In this area seismically triggered rockfalls occurred during the 1976 Friuli earthquake (Čar and Pišljar 1993) and also during the 1998 earthquake in the Krn Mountains (Gosar 2012; 2019c). Installation of TM 71 was performed in November 2004 (Šebela et al. 2005; Gosar et al. 2007). Quite a challenge was already a transport of heavy drilling equipment into the canyon and across the river. Taking into account configuration of the crack, a still rod is anchored in the western block in two points and in the eastern block in one point (Figure 5). To guarantee a sustainable installation without exposure to damage, it was important that the instrument is located under the small overhang in the wall (Figure 3a) which protects it from falling rocks and ice. The instrument is protected with a metal case (Figure 5a).

\section{Results}

The extensometer TM 71 records displacements for already 14 years. This is long enough period that it is possible to deduce on representativity of long-term displacements. The results of the first six years of measurements (end of 2004-2010) were already published in Gosar et al. 2011), but additional eight years

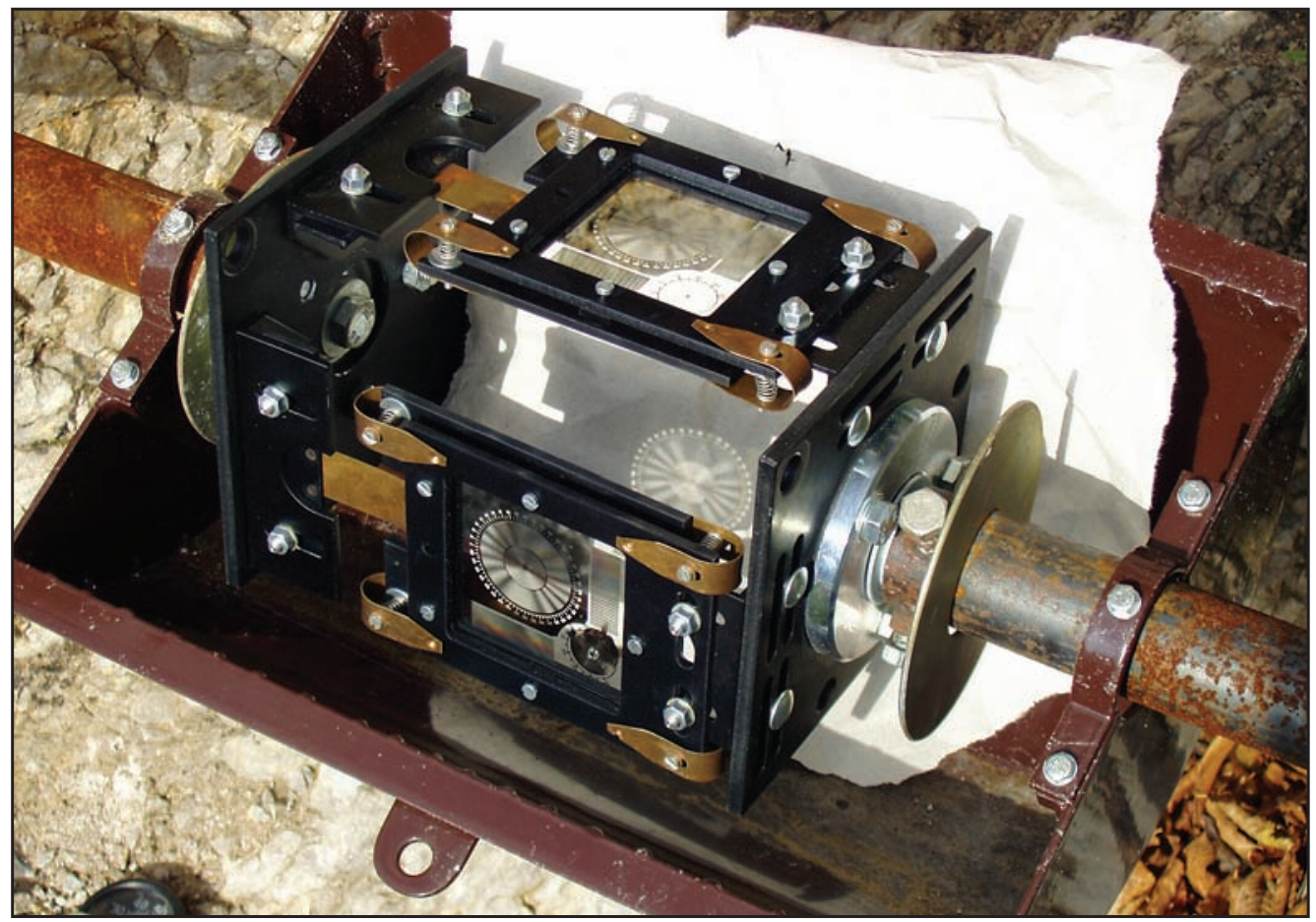

Figure 4: The TM 71 extensometer which measures tectonic micro-displacements in three directions. 
(2011-2018) of measurements allows much more firm interpretations and conclusions. The results (Figure 6) shows especially systematic trend of horizontal displacements (y-axis) and relatively smaller displacements in vertical direction (z-axis). This observation is in agreement with the fact that Idrija fault is today mainly a strike-slip fault with minor vertical component of slip (Čar and Gosar 2011). This was so far known from geological observations only. Other source of information on the sense of displacements could be seismological data. However during the last decades of detailed seismological monitoring in Slovenia and Friuli, there were no really strong earthquakes on the Idrija fault which will allow computation of focal mechanisms or detailed analysis of a coseismic slip along the fault plane (Živčić et al. 2011; Gosar 2019b). Such analyses were performed for the 1998 and 2004 earthquakes in the Krn Mountains, where focal mechanisms show on almost pure dextral slip along the Ravne fault with only minor vertical component (Bajc et al. 2001; Živčić et al. 2011; Gosar 2019a). Since Ravne and Idrija faults are parallel and both exposed to the same stress regime (compression in $\mathrm{N}-\mathrm{S}$ direction), we can deduce that also along the Idrija fault recent displacements are predominantly dextral strike-slip. However, this is not necessarily valid for all cracks within the wide fault zone (e.g. Twiss and Moores 1992). In fact measurements with TM 71 on the crack which is parallel to the main fault plane shows predominantly left-lateral strike-slip with minor vertical component. Although such a result is a surprise, a thorough discussion on possible causes at this moment is not possible. This would perhaps become possible, if detailed geodetic measurements in a dense net of points would be performed for several years. Such a survey should include a measuring points that are definitely located in a stabile blocks far outside from the fault zone, as well as within the blocks separated by individual fault planes within the outer and inner fault zones. Local permutations of the stress direction within complex fault zones are always possible, and they can result in unequal sense of movements of individual blocks also due to rotation of blocks (Twiss and Moores 1992). Therefore, in spite the whole Idrija fault clearly expresses right-lateral strike-slip movements, a displacement on a crack inside the fault zone composed of several blocks and fault planes can show opposite sense. Large scale neotectonic rotations of rigid blocks in the Adria-Eurasia collision strike-slip zones in W Slovenia were recently revealed from paleomagnetic data of Pliocene-Quaternary cave sediments (Vrabec et al. 2018). However, this large scale observation cannot be directly transferred to the local scale situation within the complex fault zone.

Average displacement rate of left-lateral slip in the first ten years (2004-2014) is $0.21 \mathrm{~mm}$ /years (Figure 6). In the first ten months after installation the velocity was even much higher $(y=+0.54 \mathrm{~mm} / \mathrm{year})$ (Gosar et al. 2011). It was followed with anomalous reading at the beginning of 2006. Although there are no direct proofs, this outlier is most probably a result of an outer mechanical influence on the instrument, which can be a falling rock or ice. This explanation is likely, because outlying reading was later completely recovered. In the first 2.5 years the average displacement rate was $0.31 \mathrm{~mm} /$ year, and in the first six years $0.24 \mathrm{~mm} /$ year (Gosar et al. 2011). This can be an indication of gradually diminishing of displacement rate

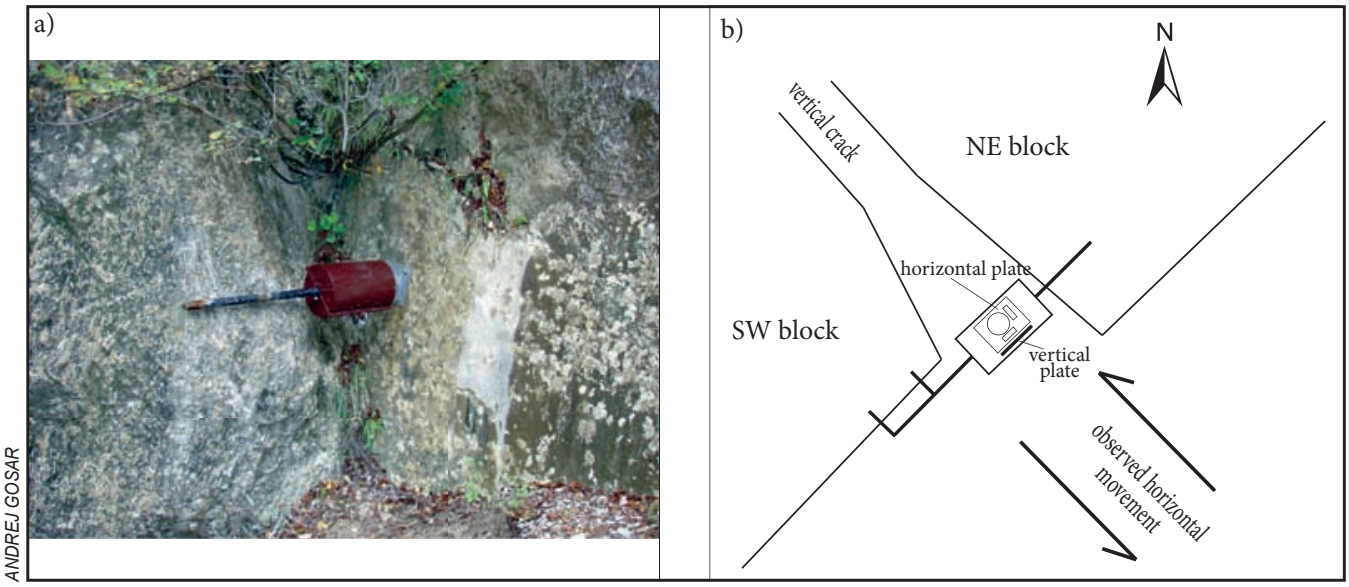

Figure 5: a) Installation of the TM 71 extensometer on a crack in the Idrija fault zone in the Učja valley. b) Schematic presentation of the installation with observed horizontal displacements (Figure 5b after Gosar 2007). 


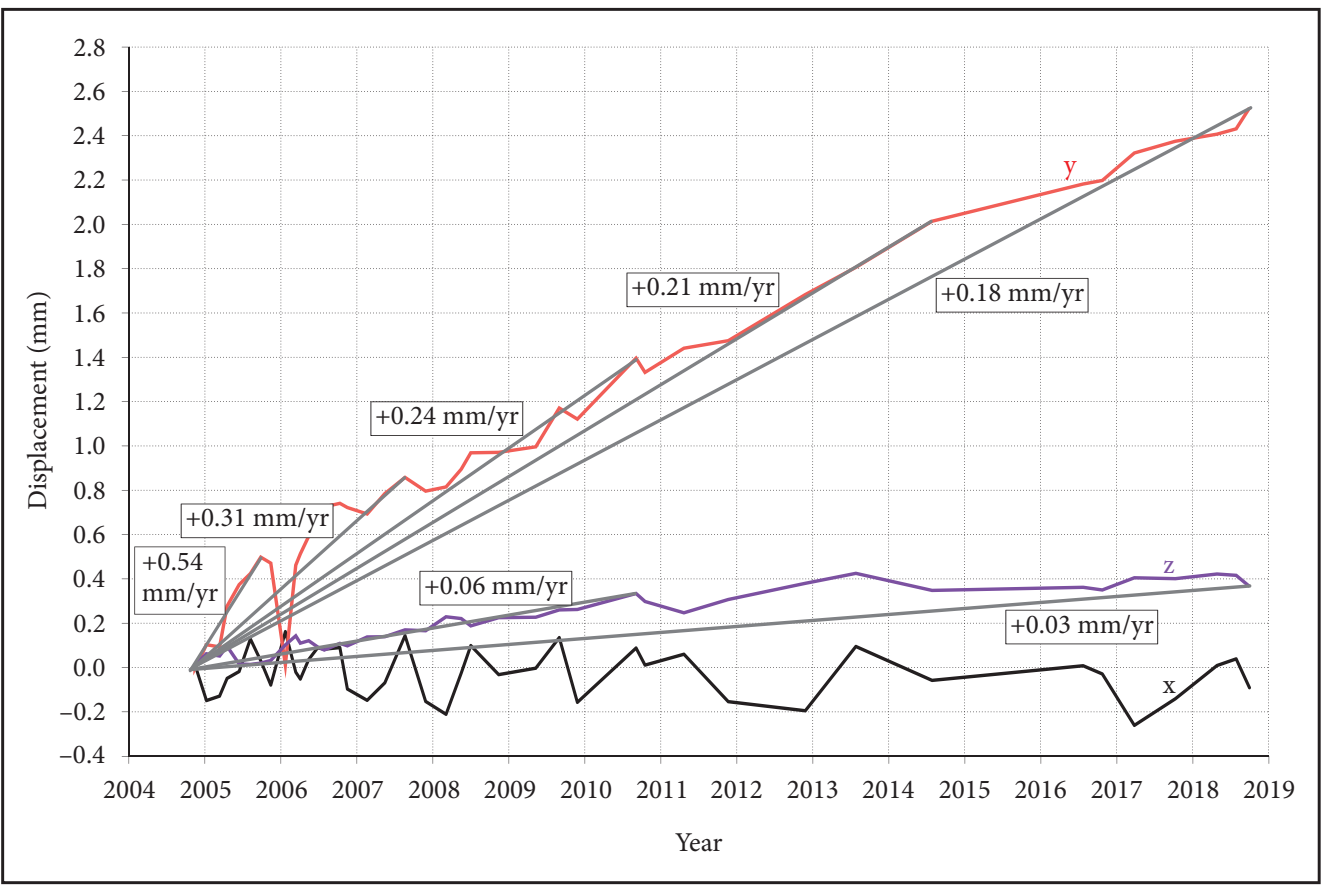

Figure 6: Displacements observed with TM 71 on the Idrija fault; +x indicates closing of the crack, +y indicates left-lateral displacement, +z indicates lowering of the SW block.

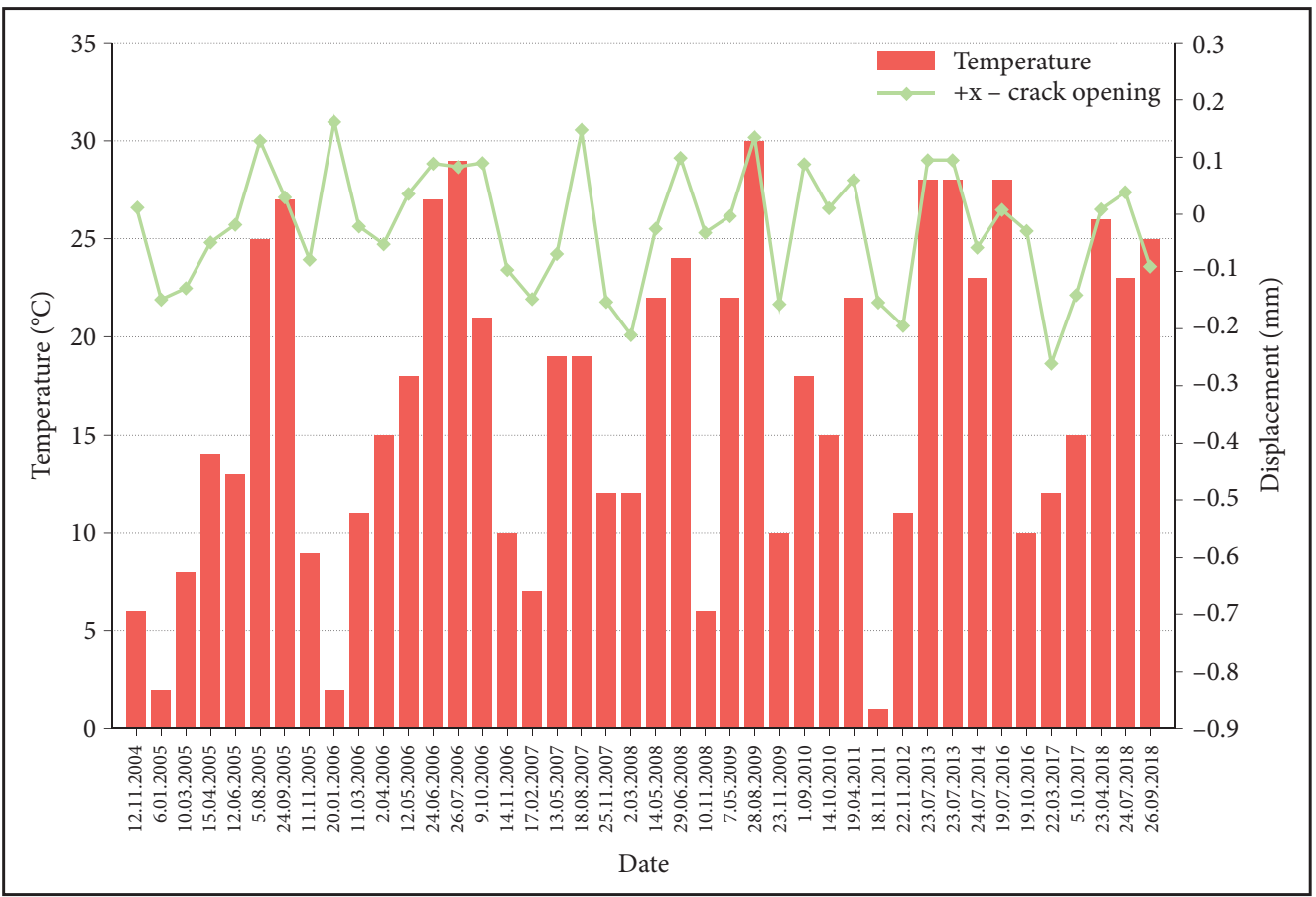

Figure 7: Correlation between temperature variations and opening (-x extension) or closing ( $+x$ compression) of the crack on the Idrija fault. 
with time. Possible reasons for this are not known. However, on 12 July, 2004 a strong earthquake with moment magnitude of 5.2 occurred in the Krn Mountains (Gosar 2019b) at the distance of 10-12 km from Učja, only five months before installation of TM 71. It is well known that large earthquakes cause a static stress change on neighbouring faults. Therefore also the Krn Mountains earthquake definitely had an influence also on the Idrija fault which runs only $8 \mathrm{~km}$ to the SW. Coulomb static stress change for 1998 and 2004 earthquakes was computed by Ganas, Gosar and Drakatos (2008) and shows slight unloading in the part of the Idrija fault near Žaga. Although this can be only a hypothesis, the stress change can have an influence on the slip-rate with diminishes with time after the earthquake. Moreover, after the year 2004 up to now there were no other strong earthquakes in the area which exceed magnitude 3.5 (Gosar 2019b). In the last years a smaller displacement rate of $0.08 \mathrm{~mm} /$ year was measured with TM 71 from mid-2014 up to the end of 2018. Taking into account the whole 14-years of observation, the average horizontal displacement rate was $0.18 \mathrm{~mm} /$ year.

On the vertical axis ( $\mathrm{z}$-axis) during first six years of observations very stable positive displacement rates were established $+0.06 \mathrm{~mm}$ /year (Gosar et al. 2011), which means relative subsidence of the SW block with respect to the NE block (Figure 6). After 2010 this rate has diminished and for the whole 14-years period it is only $+0.03 \mathrm{~mm} /$ year. For the Idrija fault prevailing strike-slip tectonics, subordinated vertical component was expected also from geological data.

The horizontal $\mathrm{x}$-axis extends in transverse direction to the crack and reflects opening or closure of the crack. As expected it shows only seasonal variations, which are in general well correlated with measured temperatures at the time of taking readings (Figures 6 and 7). Positive values (compression) corresponds to higher temperatures in summer months and negative values (extension) to lower temperatures in winter months. Observed displacements do not exceed $0.2 \mathrm{~mm}$.

Angular deformations (rotations) in both measuring planes are small (Figure 8). In the $x z$ plane they reach maximum of $+0.4 \pi / 200$ and in the $x y$ plane maximum of $-0.2 \pi / 200$. The largest deformations in the $x z$ plane were in years 2007, 2009 in 2011, but they were later mostly recovered and there is no systematic trend over the whole period of observation. On the $x y$ plane there is only a slight trend to negative values over the whole period.

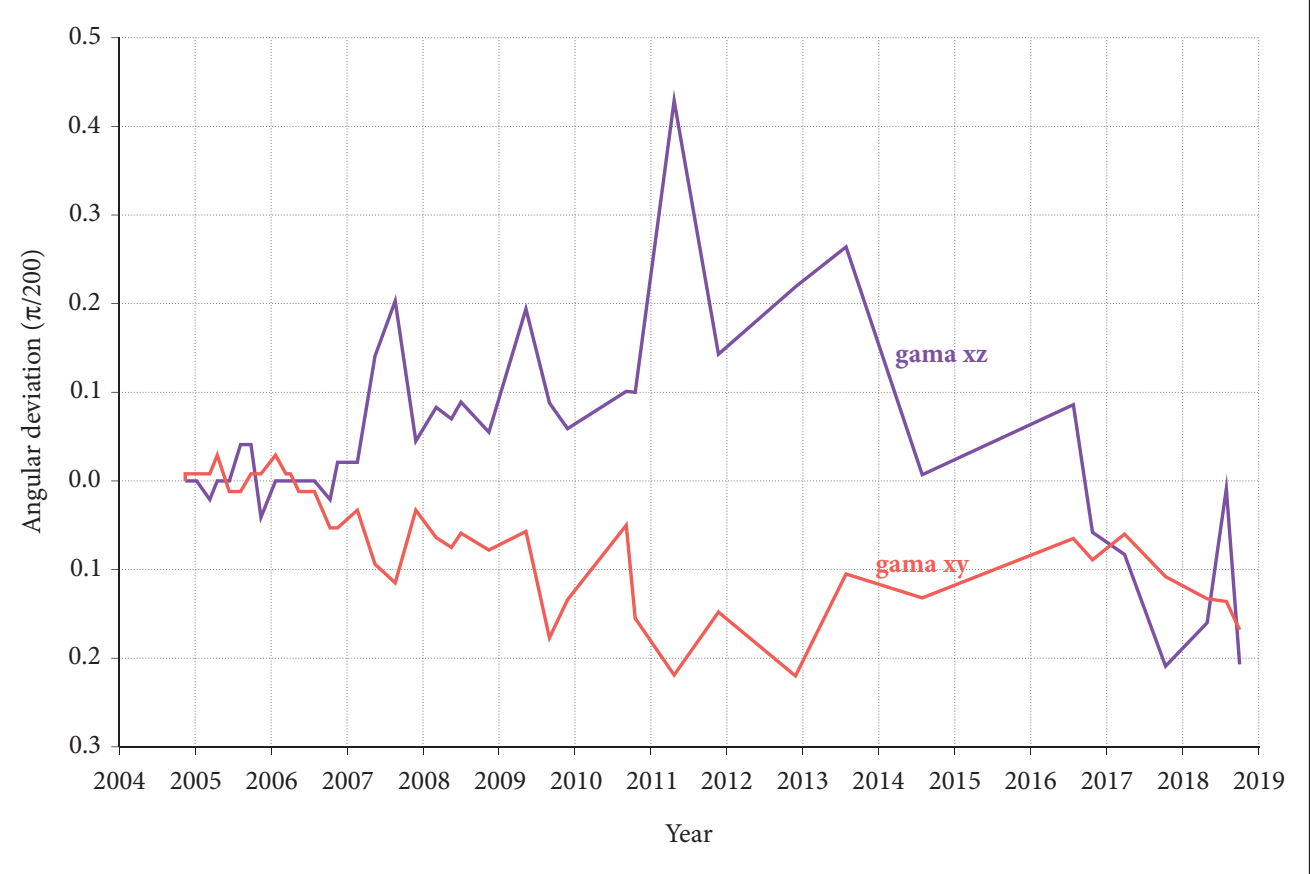

Figure 8: Angular deviations observed with TM 71 on the Idrija fault in two planes. 


\section{Discussion of results and conclusions}

Displacement measurements with TM 71 extensometer on the crack in the inner fault zone of the Idrija fault proved that this is an active fault. This is a very important result, because no direct geodetic (Kogoj 2000) or seismological (Živčić et al. 2011) proofs of its recent activity are available so far, although it was deduced from the geologic (Čar 2010), tectonic geomorphological (Cunningham et al. 2006; Moulin et al. 2016) and paleoseismological (Bavec et al. 2013) investigations that Idrija fault is an active fault.

Among all supposed active faults monitored with TM 71 extensometers in Slovenia (Gosar et al. 2011) the observed horizontal displacement rates on the Idrija fault are with the leap the highest (average rate of $0.21 \mathrm{~mm} /$ year) and with the most stable and consistent trend. The measured displacement rates on the Raša, Kneža, Predjama-Avče (Figure 1) and Brežice faults (from 0.006 to $0.05 \mathrm{~mm}$ /year) are for one order of magnitude smaller. Only measuring location on the Raša fault showed for 2.5 years a higher vertical displacement rate $(0.16 \mathrm{~mm} /$ years $)$, but later the sense of the movements has changed and the long-term average displacement trend is $0.06 \mathrm{~mm}$ /year (Gosar et al. 2011), which is the same as measured in the whole 14 -years period on the Idrija fault, but the trend on the later was stable and the sense of movements consistent in the whole period.

During the whole period the displacement trends on the Idrija fault were consistent, however the sliprate diminishes with time. This can be only hypothetically related to the static stress changes on the Idrija fault after the strong 2004 earthquake (Ganas, Gosar and Drakatos 2008). Prevailing are left-lateral horizontal displacements with average rate of $0.21 \mathrm{~mm} /$ year, and subordinated vertical displacements with the rate of $0.06 \mathrm{~mm} /$ year. For observed left-lateral displacements within dextral strike-slip fault we can only guess that they are caused by local permutation of the stress field within a complex and very wide fault zone or by rotations of the blocks. Measured displacement rates can be compared with long-term displacements estimated from the geological data, which are from 0.25 to $0.16 \mathrm{~mm} /$ year (Placer 1971). Based on tectonic geomorphology and cosmic rays exposure dating, the slip-rate of the Idrija fault for post late Pleistocene period is assessed on $1.15 \mathrm{~mm} /$ year (Moulin et al. 2016). In the frame of seismotectonic parameterisation of active faults Atanackov et al. (2014) estimated the recent slip-rate on $1 \mathrm{~mm} /$ year. GNSS measurements performed in W Slovenia revealed general movements of the territory in the north direction with velocity of 2-3 mm/year (Weber et al. 2010; Serpelloni et al. 2016). Deformations related to this movements are distributed over numerous faults of Dinaric direction which prevail in the W Slovenia (Moulin et al. 2016). In a recent study on the present-day kinematic behaviour of active faults in the Eastern Alps in Austria using TM 71 extensometers (Baroň et al. 2019), it was found that annual displacement rates of the monitored faults were mostly about an order of magnitude smaller than the rates of the entire crustal wedges revealed from GNSS measurements. This is consistent with our observations on the Idrija fault.

Comparison of deformation rates on various faults is very important for earthquake hazard assessment, especially in the W Slovenia, where active Dinaric strike-slip faults prevail. The most intriguing above all is the Idrija fault, due to rather low recent seismic activity in the last decades of instrumentally seismological monitoring (Živčić et al. 2011). This fact rises a question which of Dinaric faults could be a seismogenic sources of the strongest known historical or paleoseismological earthquakes in the region, for instance the Idrija 1511 earthquake (Fitzko et al. 2005), because these earthquakes to large extent control the seismic hazard in W Slovenia. Results of TM 71 measurements on the Idrija and Raša faults and in vicinity of the Predjama-Avče fault in the Postojna cave revealed that observed deformations are much higher on the Idrija fault, although the seismic activity in the last decades was higher in the vicinity of the Raša and Predjama-Avče faults especially with several earthquake swarms or aftershock sequences in the Ilirska Bistrica, Pivka-Knežak and Vipava valley areas (Vičič et al. 2019).

Although investigations on the active tectonics of the Dinaric fault system have been more intensive in the last decade and comprises tectonic geomorphology, paleoseismology, satellite geodesy, seismology, microdisplacement measurements etc., they still do not provide sufficient data for reliable estimates on recent slip-rates of the Idrija fault. Therefore, it would be very important to supplement them with systematic and long-term geodetic measurements in a well designed and dense network of measuring points installed on stable outcrops on both tectonic blocks separated by the fault, outside of its highly fractured fault zone (Placer and Koler 2007). Realistic data on recent rates of tectonic deformations along the Idrija fault and other Dinaric faults in the W Slovenia are beside geodynamic interpretations very important for improvement of seismotectonic models and thus for better seismic hazard assessment in this earthquakes prone area. 
ACKNOWLEDGEMENT: Installation of extensometer TM 71 was realised in the frame of the EU action COST 625 3D monitoring of active tectonic structures leaded by the Institute of Rock Structure and Mechanics of the Czech Academy of Sciences in Prague. The author is in debt to Josef Stemberk, Blahoslav Koštak and Stanka Šebela (ZRC SAZU, Karst Research Institute) for their effort in setting up micro-deformation monitoring in Slovenia and to Miloš Briestensky for maintenance of instruments in the last years. The study was realized with the support of the research program P1-0011 financed by the Slovenian Research Agency.

\section{References}

ARSO 2015: Digital elevation model of Slovenia - 1 m resolution. Slovenian Environment Agency. Ljubljana. Atanackov, J., Bavec, M., Celarc, B., Jamšek Rupnik, P., Jež, J., Novak, M., Milanič, B. 2014: Seizmotektonska parametrizacija aktivnih prelomov Slovenije. 1. del. Geološki zavod Slovenije, Ljubljana.

Atanackov, J., Jamšek Rupnik, P., Jež, J., Milanič, B., Novak, M., Celarc, B., Bavec, M. 2016: Database of active faults in Slovenia. Procedings of the $7^{\text {th }}$ International INQUA Meeting on Paleoseismology, Active Tectonics and Arheoseismology. Crestone.

Bajc, J., Aoudia, A., Saraò, A., Suhadolc, P. 2001: The 1998 Bovec-Krn mountain (Slovenia) earthquake sequence. Geophysical Research Letters 28-9. DOI: https://doi.org/10.1029/2000GL011973

Baroň, I., Plan, L., Sokol, L., Grasemann, B., Melichar, R., Mitrovic, I., Stemberk, J. 2019: Present-day kinematic behaviour of active faults in the Eastern Alps. Tectonophysics 752. DOI: https://doi.org/10.1016/ j.tecto.2018.12.024

Bavec, M., Atanackov, J., Celarc, B., Hajdas, I., Jamšek Rupnik, P., Jež, J., Kastelic, V., Milanič, B., Novak, M., Skaberne, D., Žibret, G. 2013: Evidence of Idrija fault seismogenic activity during the Late Holocene including the $1511 \mathrm{Mm} 6.8$ earthquake. Seismic hazard, critical facilities and slow active faults: proceedings of the 4th International INQUA Meeting on Paleoseismology, Active Tectonics and Archeoseismology. Aachen.

Briestenský, M., Košták, B., Stemberk, J., Petro L., Vozár, J., Fojtíková, L. 2010: Active tectonic fault microdisplacement analyses: a comparison of results from surface and underground monitoring in western Slovakia. Acta Geodynamica et Geomaterialia 7-4.

Buser, S. 1986: Osnovna geološka karta SFRJ 1 : 100.000, lista Tolmin in Videm. Zvezni geološki zavod, Beograd.

Cunningham, D., Grebby, S., Tansey, K., Gosar, A., Kastelic, V. 2006: Application of airborne LiDAR to mapping seismogenic faults in forested mountainous terrain, SE Alps, Slovenia. Geophysical Research Letters 33. DOI: https://doi.org/10.1029/2006GL027014

Čar, J. 2010: Geološka zgradba idrijsko-cerkljanskega hribovja. Tolmač h Geološki karti idrijsko-cerkljanskega hribovja med Stopnikom in Rovtami v merilu $1: 25$ 000. Geološki zavod Slovenije, Ljubljana.

Čar, J., Gosar, A. 2011: Idrijski prelom in premiki ob njem. Idrijski razgledi 56-1.

Čar, J., Pišljar, M. 1993: Presek Idrijskega preloma in potek doline Učje glede na prelomne strukture. Rudarskometalurški zbornik 40, 1-2.

Fitzko, F., Suhadolc, P., Aoudia, A., Panza, G. F. 2005: Constraints on the location and mechanism of the 1511 Western-Slovenia earthquake from active tectonics and modeling of macroseismic data. Tectonophysics 404, 1-2. DOI: https://doi.org/10.1016/j.tecto.2005.05.003

Ganas, A., Gosar, A., Drakatos, G. 2008: Static stress changes due to the 1998 and 2004 Krn Mountain (Slovenia) earthquakes and implications for future seismicity. Natural Hazards and Earth System Science 8-1. DOI: https://doi.org/10.5194/nhess-8-59-2008

GeoZS, 2016: Seizmotektonska parametrizacija aktivnih prelomov Slovenije. Geološki zavod Slovenije, Ljubljana.

Gosar, A. 2007: Monitoring of micro-deformations along Idrija and Raša faults in W Slovenia. Geologija 50-1. DOI: https://doi.org/10.5474/geologija.2007.004

Gosar, A. 2012: Application of Environmental Seismic Intensity scale (ESI 2007) to Krn Mountains 1998 $\mathrm{Mw}=5.6$ earthquake (NW Slovenia) with emphasis on rockfalls. Natural Hazards and Earth System Science 12-5. DOI: https://doi.org/10.5194/nhess-12-1659-2012

Gosar, A. 2019a: Review of geological and seismotectonic investigations related to 1998 Mw5.6 and 2004 Mw5.2 earthquakes in Krn Mountains. Geologija 62-1. DOI: https://doi.org/10.5474/geologija.2019.002 
Gosar, A. 2019b: Review of seismological investigations related to 1998 Mw5.6 and 2004 Mw5.2 earthquakes in Krn Mountains. Geologija 62-1. DOI: https://doi.org/10.5474/geologija.2019.003

Gosar, A. 2019c: The size of the area affected by earthquake induced rockfalls: Comparison of the 1998 Krn Mountains (NW Slovenia) earthquake (Mw 5.6) with worldwide data. Acta geographica Slovenica, 59-1. DOI: https://doi.org/10.3986/AGS.4845

Gosar, A., Šebela, S., Košták, B., Stemberk, J. 2007: Micro-deformation monitoring of active tectonic structures in W Slovenia. Acta Geodynamica et Geomaterialia 4-1.

Gosar, A., Šebela, S., Koštak, B., Stemberk, J. 2009: Surface versus underground measurements of active tectonic displacements detected with TM 71 extensometers in western Slovenia. Acta Carsologica 38, 2-3. DOI: https://doi.org/10.3986/ac.v38i2-3.123

Gosar, A., Šebela, S., Košták, B., Stemberk, J. 2011: On the state of the TM71 extensometer monitoring in Slovenia: Seven years of micro-tectonic displacement measurements. Acta Geodynamica et Geomaterialia 8-4.

Kogoj, D. 2000: Geodetske meritve stabilnosti tal ob tektonskih prelomih na območju Slovenije. Geodetski vestnik 44, 1-2.

Koštak, B. 1977: Terčové měřidlo TM-71 a jeho užití pro měření velmi pomalých pohybů na poruchách a trhlinách. Inž. Stavby 25-5.

Koštak, B. 1991: Combined indicator using Moire technique. Proceedings of the 3rd international symposium on field measurements in geomechanics. Oslo.

Moulin, A., Benedetti, L., Gosar, A., Jamšek Rupnik, P., Rizza, M., Bourles, D., Ritz, J.-F. 2014: Determining the present-day kinematics of the Idrija fault (Slovenia) from airborne LiDAR topography. Tectonophysics 628. DOI: https://doi.org/10.1016/j.tecto.2014.04.043

Moulin, A., Benedetti, L., Rizza, M., Jamšek Rupnik, P., Gosar, A., Bourles, D., Keddadouche, K., Aumaitre, G., Arnold, M., Guillou, V., Ritz, J.-F. 2016: The Dinaric fault system: Large-scale structure, rates of slip, and Plio-Pleistocene evolution of the transpressive northeastern boundary of the Adria microplate. Tectonics 35-10. DOI: https://doi.org/10.1002/2016TC004188

Placer, L. 1971: Nekaj osnovnih podatkov o idrijskem prelomu. Idrijski razgledi 16-1.

Placer, L. 1982: Tektonski razvoj idrijskega rudišča. Geologija 25-1.

Placer, L., Koler, B. 2007: Predlog geodetske spremljave aktivnih prelomnih con. Geologija 50-2.

Placer, L., Vrabec, M., Celarc, B. 2010: The bases for understanding of the NW Dinarides and Istria Peninsula tectonics. Geologija 53-1. DOI: https://doi.org/10.5474/geologija.2010.005

Rižnar, I., Koler, B., Bavec, M. 2007: Recent activity of the regional geologic structures in western Slovenia. Geologija 50-1. DOI: https://doi.org/10.5474/geologija.2007.009

Serpelloni, E., Vannucci G., Anderlini, L., Bennett, R. A. 2016: Kinematics, seismotectonics and seismic potential of the eastern sector of the European Alps from GPS and seismic deformation data. Tectonophysics 688. DOI: https://doi.org/10.1016/j.tecto.2016.09.026

Stemberk, J., Koštak, B., Vilimek, V. 2003:3D monitoring of active tectonic structures. Journal of Geodynamics 36, 1-2. DOI: https://doi.org/10.1016/S0264-3707(03)00042-5

Stemberk, J., Koštak, B., Cacoń, S. 2010: A tectonic pressure pulse and geodynamic activity recorded from long-term monitoring of faults in Europe. Tectonophysics 487. DOI: https://doi.org/10.1016/ j.tecto.2010.03.001

Šebela, S., Gosar, A., Koštak, B., Stemberk, J. 2005: Active tectonic structures in the W part of Slovenia setting of micro-deformation monitoring net. Acta Geodynamica et Geomaterialia 2-1.

Šebela, S., Turk, J., Mulec, J., Koštak, B., Stemberk, J. 2009: Statistical evaluation of the 3D monitoring of displacements of Dinaric Fault Zone in Postojna Cave, Slovenia. Acta Geodynamica et Geomaterialia 6-2.

Twiss, R. J., Moores, E. M. 1992: Structural geology. New York.

Vičič, B., Aoudia, A., Javed, F., Foroutan, M., Costa, G. 2019: Geometry and mechanics of the active fault system in western Slovenia. Geophysical Journal International 217-3. DOI: https://doi.org/10.1093/ gji/ggz118

Vrabec, M. 2012: Evidence of Quaternary faulting in the Idrija fault zone, Učja canyon, NW Slovenia. RMZ Materials and Geoenvironment 59, 2-3.

Vrabec, M., Preuner, P., Zupan Hajna, N., Mihevc, A., Bosak, P. 2018: Neotectonic vertical-axis rotations in the Adria-Eurasia collision zone reviled from Paleomagnetic data of Pliocene-Quaternary cave sediments (Slovenia). INQUA SEQS Quaternary Stratigraphy in Karst and Cave Sediments, Program, Abstract and Guide Book. Postojna. 
Weber, J., Vrabec, M., Pavlovčič-Prešeren, P., Dixon, T., Jiang, Y., Stopar, B. 2010: GPS-derived motion of the Adriatic microplate from Istria Peninsula and Po plain, and geodynamic implications. Tectonophysics 483, 3-4. DOI: https://doi.org/10.1016/j.tecto.2009.09.001

Žibret, G., Komac, M., Jemec Auflič, M. 2012: PSInSAR displacements related to soil creep and rainfall intensities in the Alpine foreland of western Slovenia. Geomorphology 175-176. DOI: https://doi.org/ 10.1016/j.geomorph.2012.07.002

Žibret, L., Žibret, G. 2014: Use of geomorphological indicators for the detection of active faults in southern part of Ljubljana moor, Slovenia. Acta geographica Slovenica 54-2. DOI: https://doi.org/10.3986/AGS54203

Živčić, M., Čarman, M., Gosar, A., Jesenko, T., Zupančič, P. 2011: Potresi ob Idrijskem prelomu. Idrijski razgledi 56-1. 